\title{
The Influence of the Independent Non-Executive Board Members on the Financial Performance of the Companies Listed in the Bucharest Stock Exchange
}

\author{
Bogdan Aurelian Mihail ${ }^{1, *}$ and Carmen Daniela Micu ${ }^{2}$ \\ 1 Doctoral School of Finance, Bucharest University of Economic Studies, 6 Piata Romana, \\ 010374 Bucharest, Romania \\ 2 Department of Masters in Board Practice and Directorship, Henley Business School, University of Reading, \\ Greenlands Campus, Henley-on Thames, Oxfordshire RG9 3AU, UK; carmen.micu@envisia.eu \\ * Correspondence: bog.mihail@gmail.com
}

check for updates

Citation: Mihail, Bogdan Aurelian, and Carmen Daniela Micu. 2021. The Influence of the Independent Non-Executive Board Members on the Financial Performance of the Companies Listed in the Bucharest Stock Exchange. Journal of Risk and Financial Management 14: 462. https://doi.org/10.3390/jrfm14100462

Academic Editors: Ştefan Cristian Gherghina and Stefan Bojnec

Received: 11 June 2021

Accepted: 24 September 2021

Published: 1 October 2021

Publisher's Note: MDPI stays neutral with regard to jurisdictional claims in published maps and institutional affiliations.

Copyright: (C) 2021 by the authors. Licensee MDPI, Basel, Switzerland This article is an open access article distributed under the terms and conditions of the Creative Commons Attribution (CC BY) license (https:// creativecommons.org/licenses/by/ $4.0 /)$

\begin{abstract}
This paper studies the impact of independent board members on the financial performance of companies listed on the Bucharest Stock Exchange during the period 2016-2020. Different characteristics of the board of directors have been examined extensively in the literature and board independence was identified as one of the most effective corporate governance tools. In this context, the present study contributes to the relevant literature by examining recent data for Romania and investigating alternative performance indicators such as return on assets (ROA), return on equity (ROE) and Tobin's Q. The correlation analysis, scatter plots, and regression results document that a higher share of the independent board members was associated with higher returns on equity ratio. Specifically, a $10 \%$ rise in the share of independent members was associated with an approximately $0.9 \%$-point increase in ROE.
\end{abstract}

Keywords: corporate governance; board size; firm performance; independent board members; return on equity; Romania

\section{Introduction}

Corporate governance has gained increasing importance in the management of companies in recent decades (Solomon 2020). In response to frequent and major corporate governance problems, codes of conduct were developed over time and academia examined various dimensions of corporate governance in more detail. These studies looked at the theoretical aspects of corporate governance, as well as the empirical relationship between dimensions of corporate governance (such as independent board members, board diversity, CEO-Chairman duality, and committees) and financial performance (Bhagat and Bolton 2008; Jermias and Gani 2014; Pucheta-Martínez and Gallego-Álvarez 2020). The present study contributes to this growing literature by examining the role of independent board members in company performance for public companies listed on the Bucharest Stock Exchange during the 2016-2020 period. There are some studies that look at this research question in the context of Romania. However, they generally focus on smaller samples of cross-sectional data (Borlea et al. 2017) or look at earlier periods covering the global financial crisis (Vintilă and Gherghina 2013). Hence, it is not easy to generalize the findings of these studies to more recent periods. Given that stock market capitalization as a percentage of GDP has followed a downward trend in recent years (i.e., declining from 13\% in 2013 to $10 \%$ in 2020; World Bank 2021) and stagnated at relatively low levels in Romania, it is important to examine the dynamics of stock market performance and factors affecting this performance. In this way, it can be possible to derive policy lessons to support stock market performance, and thereby economic growth, in Romania. Therefore, another important contribution of the present study is to derive important policy recommendations based on the research findings. 
As corporate governance covers a broad area, relevant studies generally focus on certain dimensions such as minority rights, CEO characteristics (e.g., the CEO-Chairperson duality and CEO participation in committees), and board characteristics (e.g., size, meeting frequency, board committees, and board diversity) (Vafeas 1999; Carter et al. 2010; Green and Homroy 2018). The relevant conceptual approaches, such as the agency theory and the resource-based view of the firm, imply that independent board members can bring unique and valuable resources to the companies and improve monitoring and supervisory efficiency (Priem and Butler 2001; Bonazzi and Islam 2007; Bhatt and Bhattacharya 2015). Independent board members could be less susceptible to managerial pressures; their experience, expertise, and networks could provide important assets for the companies; and their reputational concerns would give incentives for more effective monitoring and supervision. These theoretical mechanisms show that the presence and higher shares of independent board members can positively affect the financial performance of public companies. Given these theoretical implications, there are many studies that look at the empirical relationship between the presence and share of independent board members and the company's performance. Aggarwal et al. (2009) conducted a large cross-country analysis with firm-level data. They looked at the effect of having independent members on the board as well as the board size, CEO-Chairman duality, audit committee presences and outside members in audit committees. The authors found that board size and CEOChairman duality were not related to the company performance (measured by Tobin's Q). However, board independence had a statistically significant and positive effect on performance. In addition, their results indicated that the presence of independent board members in audit committees had a positive impact on performance as well.

Dahya et al. (2008) also conducted a detailed cross-country study on the effects of board independence. They used data from 22 countries for close to 800 firms. The authors discussed the finding from the literature that in less regulated markets in some countries, dominant shareholders could divert funds to themselves. In this context, Dahya et al. (2008) postulated that having independent board members would balance this diversion and increase firm value. In their cross-country regressions, the authors found that countries with less regulated markets also had lower levels of Tobin's Q. After controlling for the level of legal protection in the country and other relevant variables, the empirical results indicated that a higher proportion of independent directors was positively associated with higher Tobin's Q. In determining the relevant causal mechanisms, the paper showed that a higher proportion of independent board members was associated with lower levels of related party transactions or tunnelling. Therefore, they established that independent directors increased company value by decreasing the tunnelling activities of dominant shareholders. Similar positive effects of board independence were found in the cases of individual countries as well, in the UK (Dahya and McConnell 2007) and China (Liu et al. 2015). Overall, these papers provide evidence that board independence can increase company performance. However, the results might differ across countries, legal frameworks, and economic development levels. Hence, providing additional evidence from different countries can make an important contribution to the relevant literature.

The purpose of the present paper is to document the relationship between board independence and firm performance. It contributes to the literature by examining the influence of independent non-executive board members on the financial performance of companies on the Bucharest Stock Exchange during the period 2016-2020. Romania is a transition country with developing capital markets. In this context, corporate governance codes have also developed over time. Hence, examining the relationship between corporate governance and firm performance can be expected to provide valuable contributions to the relevant literature from a developing and transition country perspective. In other words, the Romanian context is appropriate for this study in order to understand the role of evolving corporate governance practices in stock market development and performance in the context of a developing country. This analysis also allows the derivation of policy lessons to support the financial and stock market development of developing and transition 
countries. As the above discussions show, there is relevant literature on the relationship between board independence and firm performance in both advanced and developing countries. There are also studies that examine similar questions in the case of the Bucharest Stock Exchange, such as Vintilă and Gherghina (2013), Vintilă et al. (2015), and Borlea et al. (2017), which are examined in more detail in the following section. Compared to these studies, the present paper uses a more recent data set from the 2016-2020 period and utilizes alternative performance measures. Hence, it expands the existing literature into different dimensions and provides some robustness analyses.

The paper is structured as follows. Section 2 presents a review of the relevant literature and states the research problem of the present study in relation to the existing literature. Section 3 presents the details of the data and research methods used in the quantitative analysis. The results of empirical analysis are given and discussed in Section 4. Finally, Section 5 concludes the paper.

\section{Literature Review}

Corporate governance is a broad concept that focuses on corporate behaviour such as "performance, efficiency, growth, financial structure, and treatment of shareholders and other stakeholders", as well as normative issues such as "the rules under which firms operate, with the rules coming from such sources as the legal system, financial markets, and factor (labor) markets" (Claessens and Yurtoglu 2012, p. 3). Within this broad literature, the focus of the present study is the influence of independent board members on the performance of companies listed on the Bucharest Stock Exchange. There are various studies that examine the relationship between corporate governance and firm performance, from both theoretical and empirical approaches and in both advanced and developing countries. In terms of theoretical models, the agency theory notes that there can be conflicts of interest between managers and shareholders or between large shareholders and minority investors (Jensen and Meckling 1976; Holderness 2003). In this context, the board of directors is expected to undertake important tasks of alleviating these agency problems (Eisenhardt 1989; Huse 1994). Alves (2014, p. 26) states that "an independent board will encourage management to focus more on the long-term performance of the firm rather than taking short-term actions intended to have a quick payoff in the stock market. In fact, boards dominated by independent outside directors may help to alleviate the agency problem by monitoring and controlling the opportunistic behaviour of management". Hence, agency theory provides supporting arguments for the positive effects of independent board members on public companies. In addition to the agency theory, the resource-based view of the firm and the stewardship theory also argue that independent board members could help firm performance (James and Joseph 2015; Glinkowska and Kaczmarek 2015; Ismail et al. 2020). Overall, the relevant theoretical approaches provide testable arguments for the performance benefits of independent board members.

In addition to elucidations of the theoretical mechanisms of the benefits of independent board members, there is a large and growing body of literature that examines this relationship empirically in both advanced and developing countries, including the case of Romania. For example, in an early study, Earle and Sapatoru (1994) examined corporate governance problems in the Romanian Private Ownership Funds (POFs). In a follow-up study, Earle and Telegdy (1998) studied the effects of the "Mass Privatization Programme (MPP), which offered shares in nearly 5000 companies to citizens in exchange for coupons" (313). The authors found that this specific privatization policy led to highly dispersed ownership, thereby creating many hardships, especially for small companies. Therefore, these two studies showed that corporate governance practices during the 1990s in Romania resulted in problems relating to incentive pay and dispersed ownership dimensions. Ioana et al. (2007) examined the evolution of corporate governance in the early 2000s. They noted there were some improvements in the corporate governance structure during the early years. However, there were some implementation issues (i.e., practice being different from legislation). In addition, there was no single corporate governance code. The authors 
recommended various public and private measures to improve corporate governance practices in Romania.

Feleagă et al. (2011) also reviewed the evolution of corporate governance in Romania. They noted that due to political, legal, and economic difficulties, the development of corporate governance frameworks in the country was gradual. The Bucharest Stock Exchange (BSE) was opened in 1995, while the first corporate governance document was adopted in 2001, which aimed at only plus category companies. However, this code was ineffective as only one company was in this category. Therefore, before the global financial crisis in 2008, Romanian stock markets suffered from various corporate governance problems. These problems included lack of analysis of manager-shareholder relations, limited shareholder involvement in business processes, weak auditing practices, lack of harmonization in accounting standards, and weak control mechanisms. Subsequently, the BSE adopted new codes in 2009, which were based on OECD guidelines. These codes were revised in 2015. The final corporate governance document included requirements and recommendations on various issues such as board responsibilities (e.g., a sufficient number of meetings and clear responsibilities for the board, management, and committees), provisions to comply with (e.g., a minimum number of board members, the share of non-executive directors, and limitations on CEO-Chairman duality), risk management (e.g., internal and independent audits), internal control (e.g., audit committee), remuneration, and investor relations (Bucharest Stock Exchange 2015). It can be argued that the current set of formal codes and guidelines are mostly consistent with best-practice corporate governance approaches in advanced countries. As a result, the relevant research questions become how effectively these guidelines are enforced and how they affect the financial performance of Romanian companies listed on the BSE. These are the questions that the current study aims to answer using recent data from the Bucharest Stock Exchange. Specifically, the present study examines a specific dimension of board characteristics, i.e., the presence and share of the independent board members, and the corresponding effects on company performance. As the relevant literature in Romania is relatively scarce, the present paper is expected to make an important contribution and extension to this literature.

There are some studies that examined very similar topics to the present paper in the case of stock market companies in the Bucharest Stock Exchange. One such study was conducted by Vintilă and Gherghina (2013). The authors focused on two properties of boards, which were board independence and CEO duality. The study first provided a review of the corporate governance codes and practices in Romania. The companies listed on the Bucharest Stock Exchange (BSE) were dominated by unitary boards. In addition, the adoption of the existing corporate codes was voluntary in the sense that firms could either adopt the relevant suggestions or explain their deviation in detail. Therefore, the corporate governance framework at the BSE followed a "comply or explain" approach. Within this context, Vintilă and Gherghina (2013) developed two research hypotheses on the positive effects of "the percentage of independent directors" and "the percentage of non-executive directors" on the firm value at the BSE. In addition, the authors postulated that the separation of CEO and Chairperson roles would also have a positive influence on companies. To test these research hypotheses, the authors collected data from the 2007-2011 period covering all firms listed in the BSE. The sample ultimately comprised 63-68 firms over different years. The study used Tobin's $Q$ as the dependent variable, while the share of independent board members, the share of non-executive board members, and CEO duality were used as the main independent variables. In addition, the firm size, leverage ratio, sales growth, and the years since listing were used as firm-specific control variables. The authors found that the average share of independent board members was relatively small, at $14 \%$. The OLS results indicated that share of independent board members had a positive but non-linear relationship with firm performance, whereas share of non-executive members and CEO duality did not have statistically significant effects. When fixed-effect regressions were estimated, the regression coefficient of the board independence also became statistically insignificant. Hence, this paper provided partial or mixed evidence 
for the influence of board independence within the BSE. In a follow-up study, Vintilă et al. (2015) used the same data set covering the 2007-2011 period for the BSE companies but expanded the list of explanatory variables. Namely, the study again used Tobin's $Q$ as the dependent variable, while including as additional independent variables board committees, board size, CEO age and tenure, and board diversity. The authors estimated two separate regressions, one with the independent variable set of board characteristics and another with the independent variable set of CEO characteristics. Their results showed that board independence was positively associated with the firm value measured by Tobin's Q. A more recent study on the present research topic was conducted by Borlea et al. (2017). In this paper, the authors tried to examine the effects of various board characteristics on stock performance (measured by ROA and Tobin's Q) of companies in the Bucharest Stock Exchange. Specifically, the study looked at the possible effects of non-executive board members, independent board members, nomination committees, competencies of board members, remuneration committees, and audit committees. Their results indicated that there were no statistically significant associations between these board characteristics and firm performance. While this paper had very broad coverage, it suffered from some research limitations. For example, the study had only a cross-sectional dataset from the sample year of 2012. In addition, information on board characteristics was collected from the "Comply or Explain Statement", which are self-reported by companies. In the case of independent board members, the relevant information was the binary answer of either Yes or No to the following question: "Does the structure of the board of directors provide a sufficient number of independent members?" (Borlea et al. 2017, p. 63). It is seen that this question can be relatively subjective and the binary answer choices did not provide very detailed information on the presence and share of independent board members. The present study significantly improves on both dimensions by examining a longer period of 2016-2020 and using the exact share of independent board members as the main independent variable.

The above studies, especially Vintilă and Gherghina (2013) and Vintilă et al. (2015), are very relevant to the present study. The present paper differs from them in several dimensions. One is the time coverage. These studies used a panel dataset covering the 2007-2011 period, which is an important advantage. However, the sample period covered the global financial crisis, which might make the findings possibly less generalizable to normal periods. In this context, the present paper provides more recent evidence using a non-financial crisis period of 2016-2020. In addition, the second study includes board characteristics and CEO properties separately into the regression model. However, the exclusion of important variables in separate regressions implies that the model might suffer from serious omitted variable bias. The present paper tries to avoid this problem by including both board and CEO characteristics in the same regression model. Finally, the present study conducts the same regression models with three different performance indicators, namely Tobin's Q, ROE, and ROA, while the above studies only focused on ROA and Tobin's $Q$. The use of ROE as the main independent variable has advantages in terms of measuring the benefits accruing to equity investors and comparing the performance of different equity investments. This dependent variable becomes important to make assessments on the attractiveness of stock markets for investors and the possible factors affecting stock market development. Overall, the present paper differs from existing studies in various dimensions, which become the contribution of the present paper to the relevant literature.

Based on the above discussions, the research question of the present study can be stated as follows: "What is the impact of the presence and proportion of independent board members on the financial performance of the companies listed on the Bucharest Stock Exchange?" Hence, the study has a clear research question which is also widely examined in the literature. In this context, the paper has several additional aims. The first aim is to collect a unique set of data on the board characteristics of the leading companies listed on the BSE. To the best of our knowledge, there are no private or public sources of data with relevant information (such as board size, number of executive and non- 
executive board members, number of independent board members, number of female board members, CEO duality information [i.e., whether the CEO holds the Chairperson position as well], and other CEO characteristics), other than the webpages and annual reports of the leading companies listed on the BSE. After this data is collected, another research aim is to display certain board characteristics, including the presence and share of independent board members, for the companies listed on the BSE. This analysis also provides valuable information on the existing conditions of corporate governance for these companies. Finally, the main aim of the present study is to document the impact of independent board members on the financial performance of companies listed on the BSE.

The above theoretical and empirical discussions show that the presence of higher shares of independent members on the board of directors can have positive effects on the financial performance of public companies. Therefore, consistent with the research question of the present study, the corresponding research hypothesis is stated as follows:

Hypothesis 1 (H1). The share of independent board members has a positive effect on the financial performance of public companies on the Bucharest Stock Exchange.

\section{Data and Research Methods}

\subsection{Sample Selection and Variable Description}

As explained in the previous section, there is no available public or private dataset that could be accessed to obtain the required variables for board and CEO characteristics. In this context, all variables were collected by hand from the annual reports of the companies. In terms of time coverage, data for the last five years from 2016 to 2020 were collected. All firms in the stock market were included in the empirical analysis. As discussed in the previous section, the data sample had some advantages over other papers focused on Romania, such as Vintilă and Gherghina (2013) and Borlea et al. (2017). For example, the former used data from the 2007-2011 period, which includes the global financial crisis, and the second paper used data only from 2012 and provided information on board characteristics in terms of self-reported binary variables (such as whether the level of independent board members is enough or not). Hence, it can be difficult to generalise the findings of these two papers. The dataset in the present paper provided information from more recent years and was suitable to obtain more robust findings. The relevant variables and their definitions are presented in Table 1. This dataset provides information on three financial performance indicators, $\mathrm{ROE}$, ROA, and Tobin's Q. In addition, various board and CEO characteristics were obtained for these companies. In this way, it became possible to check the possible effect of these board and CEO characteristics on the firm performance, thereby providing more robust findings. Hence, based on these points, the present sample can be considered one of the strengths of the paper. The selection of these variables was based on the large literature examining the effects of board and CEO characteristics on firm performance (Nelson 2005; Jermias and Gani 2014; Pucheta-Martínez and Gallego-Álvarez 2020; Naseem et al. 2020). These studies generally found positive effects on performance to result from diversity effects in terms of gender, non-executive, and independent board members, as well as positive effects resulting from women CEOs. In addition, the $\mathrm{CEO}$ duality was found to be generally negatively associated with firm performance. However, these results were not fully robust as some papers found these effects not to be statistically significant. While these general discussions are important to understand the effects of corporate governance on firm performance, examining all of these board and CEO characteristics in detail was beyond the scope of the present paper. Hence, the focus of the present study was on the effects of independent board members and the corresponding research hypothesis. 
Table 1. Description of Variables.

\begin{tabular}{cc}
\hline Variable & Definition \\
\hline Return on Equity & Net Profits as a percentage of Shareholder Equity \\
Return on Assets & Net Profits as a percentage of Total Assets \\
Tobin's Q & Market Value as a percentage of Total Assets \\
Board size & The number of members on the board \\
Non-executive Share & The number of non-executive members as a percentage of Board size \\
Independent Share & The number of independent members as a percentage of Board size \\
Women Share & The number of women members as a percentage of Board size \\
CEO Duality & Takes a value of 1 if the CEO has the dual duty of CEO and Chairperson \\
CEO Women & Takes a value of 1 if woman CEO \\
\hline
\end{tabular}

\subsection{Econometric Specification}

In terms of research methods, the present paper followed the studies in the literature closely so that results are comparable to the findings in the relevant literature. For example, O'connell and Cramer (2010) used a standard linear regression model where the financial performance indicator was the dependent variable, and various board characteristics such as board size and share of the non-executive directors on the board were the main independent variables. The regression model also included some control variables. Similar regression models have been used by other studies as well (Arora and Sharma 2016; Al Farooque et al. 2019). Therefore, the present paper also used an OLS regression equation given as follows:

$$
\begin{gathered}
\text { Firm Performance }_{i, t}=\beta_{0}+\beta_{1} \text { Size }_{i, t}+\beta_{2} \text { BoardSize }_{i, t}+ \\
\beta_{3} \text { ShareInpdenendentBoardMembers }_{i, t}+\beta_{4} \text { Controls }_{i, t}+\varepsilon_{i, t}
\end{gathered}
$$

In the above equation, $i$ refers to firm (which ranges from $i=1$ to $i=72$ ) and $t$ refers to the year (which ranges from $t=2016$ to $t=2020$ ). Consistent with the relevant literature, the return on equity (ROE) was used as the performance indicator. ROA and Tobin's $Q$ were used as alternative performance indicators. The size of the company was measured by the turnover (i.e., the total revenue). Board size (i.e., the total number of members on the company board) was the first board-related variable. In this context, the share of the independent board members was the main variable of interest for the study. The regression model also included control variables such as board and CEO characteristics. In terms of firm-specific variables, the inclusion of size as the only control variable can be considered as a data-related shortcoming. This dimension can also be expanded in future research. To see possible non-linear effects, the square of the independent share was also included in one specification of the regression estimation.

\section{Findings}

This part presents the empirical findings. The results are given in two subsections. The first subsection documents the summary statistics and correlation analysis, and the second subsection presents the regression findings.

\subsection{Summary Statistics and Correlation Analysis}

The data for the companies listed on the BSE were collected from their web pages and annual reports. Due to data availability issues, some variables were missing from the sample. Table 2 shows the statistical summary of the variables used in the analysis. 
Table 2. Statistical Summary.

\begin{tabular}{cccccc}
\hline & Obs & Mean & Std.Dev. & Min & Max \\
\hline ROE & 320 & 7.662 & 14.711 & -52.8 & 86.19 \\
ROA & 319 & 3.151 & 9.645 & -44.49 & 77.05 \\
Tobin's Q & 119 & 0.677 & 0.664 & 0 & 3.94 \\
Ln_Size & 303 & 18.282 & 1.97 & 12.37 & 23.41 \\
Board Size & 345 & 4.971 & 1.73 & 1 & 11 \\
Independent Share & 295 & 38.423 & 30.427 & 0 & 100 \\
Non-Executive Share & 345 & 67.585 & 29.602 & 0 & 100 \\
Women Share & 340 & 20.466 & 23.14 & 0 & 100 \\
CEO Duality & 320 & 0.297 & 0.458 & 0 & 1 \\
CEO Women & 330 & 0.106 & 0.308 & 0 & 1 \\
\hline
\end{tabular}

It is seen from Table 2 that there were 295 observations for the share of independent board members. In the case of other variables, the number of observations was larger than 300 , except for the variable of Tobin's $Q$ with 119 observations. In the sample, the average ROE was $7.7 \%$, with a standard deviation of $14.7 \%$. The average board size was very close to five, with an interval that ranged from 1-11. The share of independent board members averaged $38 \%$, whereas the proportion of non-executive board members averaged $68 \%$ and the proportion of women board members averaged $20 \%$. The ranges for these three indicators were from $0 \%$ to $100 \%$, implying that the variance is quite high in terms of these board characteristics. This variation could be useful to identify the impact of board characteristics on firm performance. There were also two CEO dummy variables, showing whether the $\mathrm{CEO}$ had a dual position and whether the $\mathrm{CEO}$ was a woman. Table 1 indicated that approximately $30 \%$ of the CEOs in the sample had dual positions of being the CEO and the Chairperson, and approximately $11 \%$ of CEOs were women. Figures 1 and 2 show the histogram of board size and proportion of independent board members. It is seen that there was some clustering in both variables. Namely, the board sizes were clustered at low values near three, moderate values near five, and higher values near seven. The proportion of independent board members was clustered at approximately $30 \%$ and $70 \%$. The clustered nature of the board size was important as the regression model used the clustered standard errors.

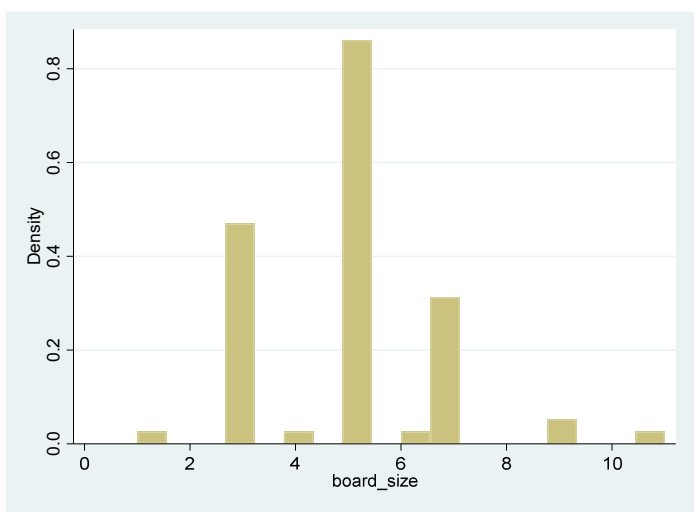

Figure 1. Board Size.

Table 3 shows the cross-correlations among the above variables. It is seen that the performance indicator of ROE was positively correlated with independent board share, but this correlation was not statistically significant at the $5 \%$ level. ROE had a negative and statistically significant correlation with the proportion of non-executive directors and negative and statistically insignificant correlations with CEO duality and CEO women indicators. 


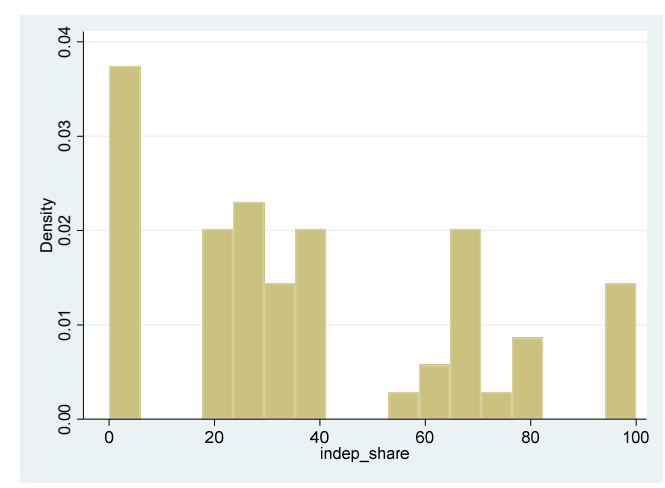

Figure 2. Share of Independent Members.

Table 3. Cross Correlations.

\begin{tabular}{|c|c|c|c|c|c|c|c|c|c|c|}
\hline Variables & (1) & (2) & (3) & (4) & (5) & (6) & (7) & (8) & (9) & (10) \\
\hline (1) roe & 1.000 & & & & & & & & & \\
\hline (2) roa & $0.405 *$ & 1.000 & & & & & & & & \\
\hline (3) tobins_q & $0.251 *$ & -0.064 & 1.000 & & & & & & & \\
\hline (4) $\ln \_$size & $0.120 *$ & $0.243 *$ & 0.129 & 1.000 & & & & & & \\
\hline (5) board_size & 0.055 & $0.140 *$ & 0.097 & $0.448 *$ & 1.000 & & & & & \\
\hline (6) indep_share & 0.053 & -0.100 & 0.181 & $-0.180 *$ & -0.039 & 1.000 & & & & \\
\hline (7) non exec share & $-0.126^{*}$ & -0.035 & 0.079 & $0.132 *$ & 0.261 * & 0.437 * & 1.000 & 1.000 & & \\
\hline (8) women_share & -0.074 & 0.063 & -0.054 & $-0.168 *$ & $-0.139 *$ & $-0.149 *$ & $-0.155^{*}$ & -0.067 & 1.000 & \\
\hline (9) ceo duality & -0.011 & 0.023 & -0.040 & -0.003 & -0.109 & -0.328 * & $-0.439 *$ & $0.220 *$ & -0.118 * & \\
\hline (10) ceo_women & -0.043 & -0.034 & 0.084 & $-0.312 *$ & -0.133 * & 0.187 * & 0.072 & 1.000 & 1.000 & 1.000 \\
\hline
\end{tabular}

${ }^{*}$ shows significance at the 0.05 level.

Figure 3 shows the scatter plot for the relationship between the financial performance indicator of ROE and the proportion of independent board members. The positive association between the two variables is evident in the graph. Hence, the correlation analysis and the scatter plot provided supportive evidence for the research hypothesis regarding the positive effects of independent board members on the profit efficiency of public companies at the Bucharest Stock Exchange. Before moving to the multiple regression analysis, the last bivariate quantitative method was to conduct a test of comparison between low and high levels of independent board member shares. For this purpose, board shares were categorised into two groups below and above the median value. The results of the parametric $t$-test and non-parametric Wilcoxon rank-sum test did not find any statistically significant differences between ROE across these groups. While these bivariate analyses provided useful insights on the research question, conducting multivariate analysis would present more robust findings as it would control for the possible effects of other relevant variables. The next subsection gives the results of the multivariate regression analysis.

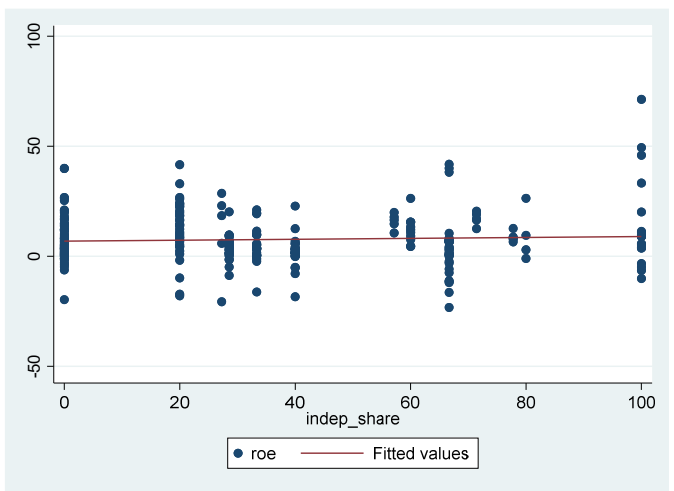

Figure 3. Scatter Plot between ROE and the Proportion of Independent Board Members. 


\subsection{Regression Analysis}

The regression results are presented in two tables. Table 4 shows the regression findings where the control variables were only the board characteristics, whereas Table 5 documents the regression results where two CEO characteristics were also added into the regression model. These regression models were estimated using the OLS regression approach, with clustering of errors based on board size. In this way, the heteroscedasticity problem in the residuals was addressed. The additional diagnostic analysis also showed that these regression models did not suffer from the multicollinearity problem.

Table 4. OLS Regression Results with Board Characteristics.

\begin{tabular}{|c|c|c|c|c|c|c|c|}
\hline ROE & Coef. & St.Err. & $t$-Value & $p$-Value & $95 \%$ Conf & . Interval & Sig \\
\hline ln_size & 1.167 & 0.389 & 3.00 & 0.024 & 0.215 & 2.119 & $* *$ \\
\hline board_size & 0.316 & 0.816 & 0.39 & 0.712 & -1.682 & 2.313 & \\
\hline indep_share & 0.057 & 0.012 & 4.79 & 0.003 & 0.028 & 0.086 & $* * *$ \\
\hline non_exec_share & -0.069 & 0.048 & -1.46 & 0.195 & -0.186 & 0.047 & \\
\hline women share & -0.030 & 0.030 & -1.00 & 0.356 & -0.105 & 0.044 & \\
\hline Constant & -12.078 & 8.289 & -1.46 & 0.195 & -32.359 & 8.204 & \\
\hline \multicolumn{2}{|c|}{ Mean dependent var } & 7.875 & \multicolumn{3}{|c|}{ SD dependent var } & 12.232 & \\
\hline \multicolumn{2}{|c|}{ R-squared } & 0.063 & \multicolumn{3}{|c|}{ Number of obs } & 236 & \\
\hline \multicolumn{2}{|c|}{$F$-test } & 295.766 & \multicolumn{3}{|c|}{ Prob $>$ F } & 0.000 & \\
\hline \multicolumn{2}{|c|}{ Akaike crit. (AIC) } & 1847.216 & \multicolumn{3}{|c|}{ Bayesian crit. (BIC) } & 1867.999 & \\
\hline
\end{tabular}

It is seen from Table 4 that the only statistically significant regression coefficient was the proportion of independent board members. The relevant regression coefficient was statistically significant at the $1 \%$ level. The model had an $\mathrm{R}^{2}$ value of 0.063 , indicating that $6.3 \%$ of the variation in financial performance could be explained by the regression model. The F-value was also statistically significant, thereby showing the relevance of the regression model and the independent variables.

Table 5. OLS Regression Results with Board and CEO Characteristics.

\begin{tabular}{|c|c|c|c|c|c|c|c|}
\hline ROE & Coef. & St.Err. & $t$-Value & $p$-Value & 95\% Conf. & Interval & Sig \\
\hline ln_size & 0.818 & 0.723 & 1.13 & 0.301 & -0.951 & 2.588 & \\
\hline board size & 0.564 & 0.812 & 0.69 & 0.513 & -1.423 & 2.550 & \\
\hline indep_share & 0.085 & 0.014 & 6.22 & 0.001 & 0.052 & 0.119 & $* * *$ \\
\hline non_exec_share & -0.137 & 0.027 & -5.00 & 0.002 & -0.203 & -0.070 & $* * *$ \\
\hline women share & -0.058 & 0.021 & -2.77 & 0.033 & -0.109 & -0.007 & $* *$ \\
\hline ceo_duality & -2.803 & 1.147 & -2.44 & 0.050 & -5.609 & 0.003 & * \\
\hline ceo_women & -1.536 & 3.119 & -0.49 & 0.640 & -9.167 & 6.095 & \\
\hline Constant & -1.065 & 15.624 & -0.07 & 0.948 & -39.295 & 37.164 & \\
\hline \multicolumn{2}{|c|}{ Mean dependent var } & 8.248 & \multicolumn{3}{|c|}{ SD dependent var } & 12.437 & \\
\hline \multicolumn{2}{|c|}{ R-squared } & 0.079 & \multicolumn{3}{|c|}{ Number of obs } & 216 & \\
\hline \multicolumn{2}{|c|}{$F$-test } & 14027 & \multicolumn{3}{|c|}{ Prob > F } & 0.000 & \\
\hline \multicolumn{2}{|c|}{ Akaike crit. (AIC) } & 1695.261 & \multicolumn{3}{|c|}{ Bayesian crit. (BIC) } & 1715.512 & \\
\hline
\end{tabular}

${ }^{* * *} p<0.01,{ }^{* *} p<0.05,{ }^{*} p<0.1$.

Table 5 includes the two CEO characteristics in the regression model. It is seen that the $\mathrm{R}^{2}$ value increased to 0.079 , indicating a higher explanatory power. In this model, the proportion of independent board members again had a positive and statistically significant impact on performance. In addition, two CEO characteristics were negatively associated with performance. Overall, both regression tables provided strong evidence that the presence of independent board members could be a positive corporate governance factor for the companies listed on the Bucharest Stock Exchange.

In terms of robustness analysis, Appendix A presents the results of additional regression estimations. Similar to Vintilă and Gherghina (2013), the square of the board independence variable was also added to the regression models in Tables A1 and A2. However, the results showed the presence of some non-linear effects in the data. Table A3 
estimated the regression with the dependent variable of ROA. In that case, the size variable became a positive predictor of the return on assets. In addition, the share of women on the board was found to have a statistically significant and positive effect on firm performance. However, board independence was not found to have any statistically significant effect. Finally, Table A4 presents the findings for the dependent variable of Tobin's Q. In that case, none of the variables had a statistically significant regression coefficient. The smaller sample in that case could be a major factor in finding weaker results. Overall, these findings show that the choice of firm performance variable can affect findings in major ways.

The findings of the above regression results provided important links to the relevant theoretical and empirical literature. The positive effects of the independent board members were consistent with the arguments of the agency theory and the resource-based view of the firm in terms of independent board members increasing the monitoring and advisory capacity of boards (Alves 2014; James and Joseph 2015). The findings were also in line with empirical literature that found positive performance effects of independent board members (Dahya et al. 2008; Aggarwal et al. 2009). Hence, the present study contributes to the relevant literature by providing supportive empirical evidence on the positive effects of the independent board members at the Bucharest Stock Exchange. There are also recent studies that examined the effects of board characteristics in Romania. For example, Vintilă and Gherghina (2013) examined the 2007-2011 period and found positive effects of independent board members. The presence of the global financial crisis years could be a factor restricting the generalisability of this study. In another paper, Borlea et al. (2017) examined the possible effects of board characteristics for the firms at the Bucharest Stock Exchange. However, their sample was restricted to 2012 and the authors did not find any statistically significant results. Hence, the present paper improved the results of the previous papers by examining a more recent period of 2016-2020, including more variables on board and CEO characteristics, and conducting various robustness analyses. The findings of the present paper also allow the derivation of some policy recommendations. The stock market capitalisation to GDP ratio is at relatively low levels in Romania and has followed a downward trend in recent years. The present findings imply that corporate governance practices, especially the presence of independent board members, can matter for firm performance. Improving corporate governance codes and practices can attract higher investor attention to the stock markets and support stock market development and economic growth in the country.

\section{Conclusions}

This paper examined the impact of independent board members on the financial performance of companies listed on the Bucharest Stock Exchange. The relevant corporate governance theories, such as the agency theory and the resource-based theory of the firm, argue that independent members would improve the monitoring capacity and supervising efficiency of the boards. In addition, empirical studies show that the presence of independent members is associated with better financial performance. When the corporate governance codes and regulations in Romania are examined, it is found that the relevant corporate governance has gradually evolved. While theoretical and empirical studies display the importance of independent board members, there are few studies that directly analyze the influence of independent board members (Vintilă and Gherghina 2013; Vintilă et al. 2015; Borlea et al. 2017). The present study contributed to this literature by collecting a unique dataset including board and CEO characteristics for the companies listed on the Bucharest Stock Exchange, and by conducting a more detailed and recent analysis on the topic. The correlation analysis, scatter plots, and regression results showed that a higher share of independent board members was associated with higher returns on equity ratio. Specifically, a 10\% rise in the independent member share was associated with an approximately $0.9 \%$ point increase in ROE. These results imply that regulations recommending the presence of independent members on boards would be useful to improve corporate governance quality and firm performance in Romania. There are some limitations in the 
present study that can be addressed in future research. For example, the present dataset did not allow for the implementation of more advanced regression techniques such as instrumental variables and difference-in-difference methods. These methods can be instrumental in addressing the possible endogeneity issues. In addition, changes in corporate governance codes can be used as events to understand the effects of corporate governance practices on firm performance. The dataset can also be improved to include more control variables related to firm characteristics such as leverage.

Author Contributions: Author Contributions: Conceptualization, B.A.M.; data curation, B.A.M. and C.D.M.; Formal analysis, B.A.M. and C.D.M.; Methodology, C.D.M.; Resources, C.D.M. All authors have read and agreed to the published version of the manuscript.

Funding: This research received no external funding.

Institutional Review Board Statement: Not applicable.

Informed Consent Statement: Not applicable.

Conflicts of Interest: The authors declare no conflict of interest.

\section{Appendix A}

Table A1. Non-Linear Model with Board Characteristics.

\begin{tabular}{|c|c|c|c|c|c|c|c|}
\hline ROE & Coef. & St.Err. & $t$-Value & $p$-Value & 95\% Conf. & Interval & Sig \\
\hline ln_size & 1.235 & 0.331 & 3.73 & 0.010 & 0.424 & 2.046 & ** \\
\hline board size & 0.261 & 0.823 & 0.32 & 0.762 & -1.753 & 2.275 & \\
\hline indep_share & -0.104 & 0.161 & -0.65 & 0.541 & -0.498 & 0.290 & \\
\hline indep_square & 0.002 & 0.002 & 1.02 & 0.348 & -0.002 & 0.006 & \\
\hline non_exec_share & -0.049 & 0.067 & -0.74 & 0.489 & -0.214 & 0.115 & \\
\hline women share & -0.019 & 0.050 & -0.37 & 0.722 & -0.142 & 0.105 & \\
\hline Constant & -12.602 & 6.929 & -1.82 & 0.119 & -29.555 & 4.352 & \\
\hline \multicolumn{2}{|c|}{ Mean dependent var } & 7.875 & \multicolumn{2}{|c|}{ SD dependent var } & \multicolumn{2}{|c|}{12.232} & \\
\hline \multirow{2}{*}{\multicolumn{2}{|c|}{$\begin{array}{c}\text { R-squared } \\
\text { F-test }\end{array}$}} & 0.079 & \multicolumn{2}{|c|}{ Number of obs } & \multicolumn{2}{|c|}{236.000} & \\
\hline & & $1.8 \times 10^{5}$ & \multicolumn{2}{|c|}{ Prob $>$ F } & \multicolumn{2}{|c|}{0.000} & \\
\hline \multicolumn{2}{|c|}{ Akaike crit. (AIC) } & 1843.277 & \multicolumn{2}{|c|}{ Bayesian crit. (BIC) } & \multicolumn{2}{|c|}{1864.060} & \\
\hline
\end{tabular}

Table A2. Non-Linear Model with Board and CEO Characteristics.

\begin{tabular}{|c|c|c|c|c|c|c|c|}
\hline ROE & Coef. & St.Err. & $t$-Value & $p$-Value & 95\% Conf & . Interval & Sig \\
\hline ln_size & 0.987 & 0.633 & 1.56 & 0.170 & -0.563 & 2.537 & \\
\hline board size & 0.589 & 0.828 & 0.71 & 0.504 & -1.437 & 2.614 & \\
\hline indep_share & -0.111 & 0.171 & -0.65 & 0.541 & -0.529 & 0.308 & \\
\hline indep_square & 0.002 & 0.002 & 1.03 & 0.342 & -0.003 & 0.007 & \\
\hline non_exec_share & -0.126 & 0.033 & -3.78 & 0.009 & -0.208 & -0.045 & $* * *$ \\
\hline women share & -0.054 & 0.040 & -1.34 & 0.227 & -0.152 & 0.044 & \\
\hline ceo_duality & -2.601 & 1.242 & -2.10 & 0.081 & -5.640 & 0.437 & * \\
\hline ceo_women & 0.205 & 2.268 & 0.09 & 0.931 & -5.345 & 5.755 & \\
\hline Constant & -2.984 & 14.158 & -0.21 & 0.840 & -37.627 & 31.660 & \\
\hline \multicolumn{2}{|c|}{ Mean dependent var } & 8.248 & \multicolumn{2}{|c|}{ SD dependent var } & \multicolumn{2}{|c|}{12.437} & \\
\hline \multicolumn{2}{|c|}{ R-squared } & 0.101 & \multicolumn{2}{|c|}{ Number of obs } & \multicolumn{2}{|c|}{216.000} & \\
\hline \multicolumn{2}{|c|}{$F$-test } & 1602.6 & \multicolumn{2}{|c|}{ Prob $>F$} & \multicolumn{2}{|c|}{0.000} & \\
\hline \multicolumn{2}{|c|}{ Akaike crit. (AIC) } & 1689.910 & \multicolumn{2}{|c|}{ Bayesian crit. (BIC) } & \multicolumn{2}{|c|}{1710.161} & \\
\hline
\end{tabular}

$\overline{* * *} p<0.01,{ }^{*} p<0.1$. 
Table A3. Regression Model for ROA.

\begin{tabular}{|c|c|c|c|c|c|c|c|}
\hline ROA & Coef. & St.Err. & $t$-Value & $p$-Value & 95\% Conf. & Interval & Sig \\
\hline ln_size & 1.044 & 0.354 & 2.95 & 0.026 & 0.179 & 1.910 & $* *$ \\
\hline board size & 0.410 & 0.584 & 0.70 & 0.508 & -1.018 & 1.838 & \\
\hline indep_share & -0.035 & 0.048 & -0.72 & 0.499 & -0.152 & 0.083 & \\
\hline non_exec_share & 0.042 & 0.017 & 2.40 & 0.053 & -0.001 & 0.084 & * \\
\hline women share & 0.048 & 0.019 & 2.54 & 0.044 & 0.002 & 0.095 & $* *$ \\
\hline ceo_duality & -0.069 & 1.453 & -0.05 & 0.964 & -3.625 & 3.487 & \\
\hline ceo_women & 2.115 & 1.285 & 1.65 & 0.151 & -1.028 & 5.259 & \\
\hline Constant & -20.481 & 3.214 & -6.37 & 0.001 & -28.345 & -12.616 & $* * *$ \\
\hline \multicolumn{2}{|c|}{ Mean dependent var } & \multicolumn{2}{|c|}{3.759} & \multicolumn{2}{|c|}{ SD dependent var } & 9.444 & \\
\hline \multicolumn{2}{|c|}{ R-squared } & \multicolumn{2}{|c|}{0.103} & \multicolumn{2}{|c|}{ Number of obs } & 214.000 & \\
\hline \multicolumn{2}{|c|}{$F$-test } & \multicolumn{2}{|c|}{16.64} & \multicolumn{2}{|c|}{ Prob $>$ F } & 0.002 & \\
\hline \multicolumn{2}{|c|}{ Akaike crit. (AIC) } & \multicolumn{2}{|c|}{1556.144} & \multicolumn{2}{|c|}{ Bayesian crit. (BIC) } & 1576.339 & \\
\hline
\end{tabular}

Table A4. Regression Model for Tobin's Q.

\begin{tabular}{|c|c|c|c|c|c|c|c|}
\hline Tobin's Q & Coef. & St.Err. & $t$-Value & $p$-Value & 95\% Conf. & Interval & Sig \\
\hline ln_size & 0.070 & 0.043 & 1.63 & 0.154 & -0.035 & 0.176 & \\
\hline board size & 0.002 & 0.049 & 0.05 & 0.964 & -0.118 & 0.123 & \\
\hline indep_share & 0.004 & 0.007 & 0.51 & 0.627 & -0.014 & 0.022 & \\
\hline non_exec_share & 0.002 & 0.006 & 0.35 & 0.736 & -0.012 & 0.015 & \\
\hline women share & -0.003 & 0.002 & -1.68 & 0.143 & -0.007 & 0.001 & \\
\hline ceo_duality & 0.013 & 0.135 & 0.10 & 0.924 & -0.316 & 0.343 & \\
\hline ceo_women & 0.353 & 0.289 & 1.23 & 0.266 & -0.353 & 1.059 & \\
\hline Constant & -0.815 & 0.602 & -1.35 & 0.225 & -2.288 & 0.659 & \\
\hline \multicolumn{2}{|c|}{ Mean dependent var } & 0.787 & \multicolumn{3}{|c|}{ SD dependent var } & 0.740 & \\
\hline \multicolumn{2}{|c|}{ R-squared } & 0.075 & \multicolumn{3}{|c|}{ Number of obs } & 79.000 & \\
\hline \multicolumn{2}{|c|}{$F$-test } & 16.51 & \multicolumn{3}{|c|}{ Prob $>$ F } & 0.002 & \\
\hline \multicolumn{2}{|c|}{ Akaike crit. (AIC) } & 181.529 & \multicolumn{3}{|c|}{ Bayesian crit. (BIC) } & 195.746 & \\
\hline
\end{tabular}

\section{References}

Aggarwal, Reena, Isil Erel, René Stulz, and Rohan Williamson. 2009. Differences in governance practices between US and foreign firms: Measurement, causes, and consequences. The Review of Financial Studies 22: 3131-69. [CrossRef]

Al Farooque, Omar, Wonlop Buachoom, and Nam Hoang. 2019. Interactive effects of executive compensation, firm performance and corporate governance: Evidence from an Asian market. Asia Pacific Journal of Management 36: 1111-64. [CrossRef]

Alves, Sandra. 2014. The effect of board independence on the earnings quality: Evidence from Portuguese listed companies. Australasian Accounting, Business and Finance Journal 8: 23-44. [CrossRef]

Arora, Akshita, and Chandan Sharma. 2016. Corporate Governance and Firm Performance in Developing Countries: Evidence from India. Corporate Governance 16: 420-36. [CrossRef]

Bhagat, Sanjai, and Brian Bolton. 2008. Corporate governance and firm performance. Journal of Corporate Finance 14: 257-73. [CrossRef]

Bhatt, R. Rathish, and Sujoy Bhattacharya. 2015. Do board characteristics impact firm performance? An agency and resource dependency theory perspective. Asia-Pacific Journal of Management Research and Innovation 11: 274-87. [CrossRef]

Bonazzi, Livia, and Sardar MN Islam. 2007. Agency theory and corporate governance: A study of effectiveness of board in their monitoring of the CEO. Journal of Modelling in Management. [CrossRef]

Borlea, Sorin Nicolae, Monica Violeta Achim, and Codruța Mare. 2017. Board characteristics and firm performances in emerging economies. Lessons from Romania. Economic Research-Ekonomska Istraživanja 30: 55-75. [CrossRef]

Bucharest Stock Exchange. 2015. Code of Corporate Governance. Available online: https://www.bvb.ro/info/Rapoarte/Diverse/ ENG_Corporate\%20Governance\%20Code_WEB_revised.pdf (accessed on 5 March 2021).

Carter, David A., Frank D'Souza, Betty J. Simkins, and W. Gary Simpson. 2010. The gender and ethnic diversity of US boards and board committees and firm financial performance. Corporate Governance: An International Review 18: 396-414. [CrossRef]

Claessens, Stijn, and B. Burcin Yurtoglu. 2012. Corporate Governance and Development-An Update. A Corporate Governance Forum Publication. Washington, DC: World Bank.

Dahya, Jay, and John J. McConnell. 2007. Board composition, corporate performance and Cadbury committee recommendation. Journal of Financial and Quantitative Analysis 42: 535-64. [CrossRef]

Dahya, Jay, Orlin Dimitrov, and John J. McConnell. 2008. Dominant Shareholders, corporate boards and corporate value: A crosscountry analysis. Journal of Financial Economics 87: 73-100. [CrossRef]

Earle, John S., and Álmos Telegdy. 1998. The results of mass privatization in Romania: A first empirical study. Economics of Transition 6: 313-32. [CrossRef] 
Earle, John S., and Dana Sapatoru. 1994. Incentive contracts, corporate governance and privatization funds in Romania. Atlantic Economic Journal 22: 61-79. [CrossRef]

Eisenhardt, Kathleen M. 1989. Agency theory: An assessment and review. Academy of Management Review 14: 57-74. [CrossRef]

Feleagă, Niculae, Liliana Feleagă, Voicu Dan Dragomir, and Adrian Doru Bigioi. 2011. Corporate Governance in Emerging Economies: The Case of Romania. Theoretical \& Applied Economics 18: 5-16.

Glinkowska, Beata, and Boguslaw Kaczmarek. 2015. Classical and modern concepts of corporate governance (Stewardship Theory and Agency Theory). Management 19: 84. [CrossRef]

Green, Colin P., and Swarnodeep Homroy. 2018. Female directors, board commmittees and firm performance. European Economic Review 102: 19. [CrossRef]

Holderness, Clifford G. 2003. A survey of blockholders and corporate control. Economic Policy Review 9: 1. [CrossRef]

Huse, Morten. 1994. Board-management relations in small firms: The paradox of simultaneous independence and interdependence. Small Business Economics 6: 55-72. [CrossRef]

Ioana, Duca, Rodica Gherghina, Ciocirlan Doinita, Mariana Vuta, Stefanescu Aurelia, Monica Dudian, Carmen Trica, and Iulia Mirela Chivu. 2007. Corporate Governance Practices' Implementation in Romania-Achievements, Deficiencies, Action Items. Paper presented at the 47th Congress of the European Regional Science Association ERSA, Paris, France, 29 August-2 September.

Ismail, Aida Maria, Siti Muliyana Ahmadi, Normahiran Yatim, and Puteh Mariam Ismail. 2020. The Impact of Board Characteristics on Co-operative Reputation From the Lense of Resource-Based View Theory (RBVT). International Journal of Financial Research 11: 43-61. [CrossRef]

James, Bernadette Josephine, and Corina Joseph. 2015. Corporate governance mechanisms and bank performance: Resource-based view. Procedia Economics and Finance 31: 117-23. [CrossRef]

Jensen, Michael C., and William H. Meckling. 1976. Theory of the firm: Managerial behavior, agency costs and ownership structure. Journal of Financial Economics 3: 305-60. [CrossRef]

Jermias, Johnny, and Lindawati Gani. 2014. The impact of board capital and board characteristics on firm performance. The British Accountig Review 46: 135-53. [CrossRef]

Liu, Yu, Mihail K. Miletkov, Zuobao Wei, and Tina Yang. 2015. Board independence and firm performance in China. Journal of Corporate Finance 30: 223-44. [CrossRef]

Naseem, Muhammad Akram, Jun Lin, Ramiz ur Rehman, Muhammad Ishfaq Ahmad, and Rizwan Ali. 2020. Does capital structure mediate the link between CEO characteristics and firm performance? Management Decision 58: 164-81. [CrossRef]

Nelson, James. 2005. Corporate governance practices, CEO characteristics and firm performance. Journal of Corporate Finance 11: 197-228. [CrossRef]

O'connell, Vincent, and Nicole Cramer. 2010. The relationship between firm performance and board characteristics in Ireland. European Management Journal 28: 387-99. [CrossRef]

Priem, Richard L., and John E. Butler. 2001. Is the resource-based "view" a useful perspective for strategic management research? Academy of Management Review 26: 22-40.

Pucheta-Martínez, María Consuelo, and Isabel Gallego-Álvarez. 2020. Do board characteristics drive firm performance? An international perspective. Review of Managerial Science 14: 1251-97. [CrossRef]

Solomon, Jill. 2020. Corporate Governance and Accountability. Hoboken: John Wiley \& Sons.

Vafeas, Nikos. 1999. Board meeting frequency and firm performance. Journal of Financial Economics 53: 113-42. [CrossRef]

Vintilă, Georgeta, and Stefan Cristian Gherghina. 2013. Board of directors independence and firm value: Empirical evidence based on thr Bucharest stock exchange listed companies. International Journal of Economics and Financial Issues 3: 885.

Vintilă, Georgeta, Mihaela Onofrei, and Ştefan Cristian Gherghina. 2015. The effects of corporate board and CEO characteristics on firm value: Empirical evidence from listed companies on the Bucharest stock exchange. Emerging Markets Finance and Trade 51: 1244-60. [CrossRef]

World Bank. 2021. Market Capitalization of Listed Domestic Companies (\% of GDP)—Romania. Available online: https://data. worldbank.org/indicator/CM.MKT.LCAP.GD.ZS?locations=RO (accessed on 5 March 2021). 